\title{
PERTUMBUHAN DAN HASIL TANAMAN JAGUNG (Zea Mays L.) TERHADAP PEMBERIAN BEBERAPA KOMPOSISI PUPUK MAJEMUK PADA LAHAN PASCA TAMBANG BATUBARA
}

\author{
Syamad Ramayana1, Suria Darma Idris ${ }^{1}$, Rusdiansyah ${ }^{1}$, Krisna Fajar Madjid ${ }^{2}$ \\ ${ }^{1}$ Staf Pengajar Fakultas Pertanian Universitas Mulawarman, Samarinda \\ ${ }^{2}$ Mahasiswa Program Sarjana Fakultas Pertanian Universitas Mulawarman, Samarinda \\ ${ }^{1}$ Agroteknologi, Fakultas Pertanian, Universitas 17 Agustus 1945 Samarinda 75124, \\ Indonesia. \\ E-Mail: syamadramayana@gmail.com, suriadarmaidris@gmail.com
}

\begin{abstract}
ABSTRAK
Pertumbuhan Dan Hasil Tanaman Jagung (Zea Mays L.) Terhadap Pemberian Beberapa Komposisi Pupuk Majemuk Pada Lahan Pasca Tambang Batubara. Penelitian ini bertujuan untuk mengetahui pertumbuhan dan hasil tanaman jagung (Zea mays L.) terhadap pemberian beberapa jenis kandungan pupuk majemuk pada lahan pasca tambang batubara dan mengetahui jenis kandungan pupuk majemuk terbaik untuk pertumbuhan dan hasil tanaman jagung (Zea mays L.) pada lahan pasca tambang batubara. Penelitian dilaksanakan di lahan pasca tambang batubara Desa Bangun Rejo, Kecamatan Tenggarong Seberang, Kabupaten Kutai Kartanegara, Kalimantan Timur. Penelitian menggunakan Rancangan Acak Kelompok (RAK) dengan satu faktor yaitu pemberian beberapa pupuk majemuk (P), terdiri dari 5 taraf dan 5 ulangan yaitu p0= Tanpa Pupuk; p1 $500 \mathrm{~kg} \cdot \mathrm{ha}^{-1} \mathrm{NPK}$ 20:10:10 setara 4,2 kg.petak ${ }^{-1} ; \mathrm{p} 2=500 \mathrm{~kg} \cdot \mathrm{ha}^{-1} \mathrm{NPK}$ 17:9:11

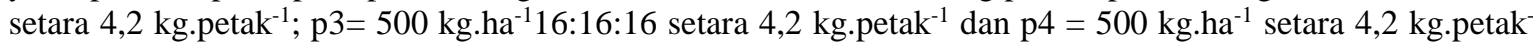
${ }^{1} 15: 20: 13$ setara 4,2 kg.petak ${ }^{-1}$. Hasil penelitian menunjukkan bahwa pemberian beberapa komposisi pupuk majemuk berbeda tidak nyata terhadap semua parameter yang diamati yaitu tinggi tanaman, diameter batang, jumlah daun, panjang tongkol, diameter tongkol, jumlah baris biji, jumlah biji dalam baris, berat biji per tongkol, berat biji per 100 butir, dan potensi hasil.
\end{abstract}

Kata kunci : Hasil, Jagung, Lahan Pasca Tambang Batubara, Pertumbuhan, Pupuk majemuk.

\begin{abstract}
Growth and Yield of Corn (Zea Mays L.) On Giving Several Composition of Compound Fertilizer in ExCoal Mining Land. This research aims to determine the growth and yield of Corn crops (Zea mays L.) on the provision of several types of compound fertilizer content in postcoal mining land and to find out The best type of compound fertilizer content for the growth and yield of corn crops (Zea mays L.) in In Ex-Coal Mining Land. coal mine. The research was conducted in In Ex-Coal Mining Land in Bangun Rejo Village, Tenggarong Seberang District, Kutai Kartanegara Regency, East Kalimantan. The research used a randomized complete block design (RCBD) with one factor, namely the application of several compound fertilizers $(P)$, consisting of 5 levels and 5 replications, namely $p 0=$ without fertilizer; $p 1=500 \mathrm{~kg} \cdot \mathrm{ha}^{-1} \mathrm{NPK}$ 20:10:10 equivalent to $4.2 \mathrm{~kg}$. plot ${ }^{-1} ; \mathrm{p} 2=500 \mathrm{~kg} \cdot \mathrm{ha}^{-1} \mathrm{NPK}$ 17: 9: 11 equivalent to $4.2 \mathrm{~kg}$. plot ${ }^{-1} ; \mathrm{p} 3=500$ kg.ha-1 16:16:16 equaling $4.2 \mathrm{~kg}$. plot ${ }^{-1}$ and $p 4=500 \mathrm{~kg} \cdot \mathrm{ha}^{-1} \mathrm{NPK}$ 15:20:13 equivalent to $4.2 \mathrm{~kg}$. plot ${ }^{-1}$. The results showed that the application of some composition fertilizer content was not significantly different for all observed parameters, namely The height of the plant, the diameter of the stem, number of leaves, length of cobs, diameter of cobs, number of seed rows, number of seeds in rows, weight of seeds per cob, The weight of the seeds per 100 grains, and yield potential.
\end{abstract}

Key words : Compound Fertilizer, Corn, Growth, Yield, Post Coal Mining Land. 


\section{PENDAHULUAN}

Berdasarkan Grand Design Rencana Tata Ruang dan Wilayah 20162036, Kalimantan Timur memiliki luas 12.920.388 ha. Peruntukan lahan bagi pengembangan pertanian secara luas 3.700 .000 ha yang meliputi perikanan 91.492 ha, perkebunan 3.269.478 ha serta pangan dan hortikultura 412.695 ha (Bappeda Propinsi Kaltim, 2016). Peruntukan lahan untuk pengembangan pertanian kaitannya dalam menunjang ketahanan pangan masih berpeluang untuk dapat ditingkatkan luasannya dengan memanfaatkan lahan pasca penambangan batubara yang selama ini potensi itu terkesan seperti terabaikan.

Namun demikian diperlukan beberapa tindakan untuk menanggulangi faktor pembatas lahan yang menjadi kendala sehingga memungkinkan pengembangannya untuk pertanian tanaman pangan dengan tetap menjaga peranannya sebagai stabilisasi dan peningkatan fungsi ekosistem. Lahan pasca tambang batubara merupakan lahan marginal yang miskin unsur hara (Dariah dkk., 2010), karena pasokan unsur hara pada tanaman tidak memadai (Kumar, 2013; Kumar dan Pandey, 2013) sehingga lahan tidak dapat lagi memberikan dukungan terhadap pertumbuhan tanaman (Ramayana, 2015).

Pengelolaan kesuburan tanah merupakan bagian dari teknologi untuk meningkatkan produktivitas lahan pasca tambang. Pemupukan adalah salah satu teknologi pengelolaan kesuburan tanah yang diharapkan dapat meningkatkan produktivitas tanah pada level yang tinggi, namun penerapannya harus dilakukan secara tepat sesuai dengan kebutuhannya. Menurut Hadijah (2010) tanaman tidak akan memberikan hasil yang maksimal apabila unsur hara yang dibutuhkan untuk pertumbuhan dan perkembangannya tidak cukup tersedia terutama unsur $\mathrm{N}, \mathrm{P}$, dan $\mathrm{K}$.
Jagung (Zea mays L.) merupakan salah satu komoditas utama tanaman pangan yang mempunyai peranan penting dan strategis dalam peningkatan perekonomian Indonesia. Komoditas ini mempunyai fungsi multiguna, baik untuk konsumsi langsung, sebagai bahan baku utama industri pakan dan industri pangan, dan bahkan dibanyak negara sudah dimanfaatkan sebagai bahan baku bioenergi (Sulaiman dkk., 2018). Penanaman jagung pada lahan pasca tambang batubara diharapkan menjadi alternatif sumber diversifikasi pangan selain padi dan kedelai dalam menunjang ketahanan pangan.

Tanaman dapat tumbuh dengan optimal bila dosis pupuk yang diberikan tepat. Penambahan sumber hara melalui pemupukan diharapkan dapat meningkatkan hasil panen baik secara kuantitatif maupun kualitatif (Fadwiwati dan Tahir, 2013). Pupuk merupakan kunci dari kesuburan tanah untuk menggantikan unsur hara yang terangkut saat panen dan mengganti unsur hara yang hilang karena pencucian. Cooke (2015) menambahkan hara N, P dan K merupakan hara yang sangat dibutuhkan tanaman jagung untuk tumbuh dan berproduksi, dimana untuk setiap ton biji yang dihasilkan memerlukan $27,4 \mathrm{~kg} \mathrm{~N}$, $4,8 \mathrm{~kg} \mathrm{P}$ dan $18,4 \mathrm{~kg} \mathrm{~K}$.

Nitrogen diperlukan untuk pertumbuhan vegetatif tanaman seperti akar, batang dan daun pembentukan karbohidrat, protein, lemak dan persenyawaan organik lain Iskandar, 2013). Fosfor untuk pertumbuhan dan hasil tanaman, yang berperan penting dalam memacu terbentuknya bunga, bulir pada malai, memperkuat jerami sehingga tidak rebah dan memperbaiki kualitas gabah (Mulyani 2010). Peranan utama Kalium bagi tanaman adalah sebagai aktivator berbagai enzim yang berperan dalam proses metabolisme dan memacu translokasi karbohidrat dari daun ke 
organ tanaman (Lingga dan Marsono, 2010).

\section{METODA PENELITIAN}

\subsection{Tempat dan Waktu}

Penelitian dilaksanakan di lahan pasca tambang batubara Desa Bangun Rejo, Kecamatan Tenggarong Seberang, Kabupaten Kutai Kartanegara, Kalimantan Timur.Waktu penelitian selama 4 bulan, yaitu dari bulan Juni 2020 sampai September 2020 yang meliputi persiapan, observasi dan pengamatan lapangan, pengambilan dan analisis data, serta penulisan akhir laporan.

\subsection{Bahan dan Alat}

Alat yang digunakan cangkul, parang, kertas label, penggaris, meteran, jangka sorong, timbangan, tali rafia, ajir (dari kayu), tugal, alat tulis, computer, dan hand tractor. Sementara bahan yang digunakan benih jagung hibrida (NK 212), pupuk majemuk (NPK) dengan kandungan pupuk NPK 20:10:10, NPK 17:9:11, NPK 16:16:16, NPK 15:20:13, kapur dolomit dan pestisida matador.

\subsection{Rancangan Penelitian}

Penelitian menggunakan Rancangan Acak Kelompok (RAK) dengan satu faktor yaitu pemberian beberapa komposisis pupuk majemuk (P), terdiri dari 5 taraf dan 5 ulangan yaitu p0= Tanpa Pupuk; p1 $=500$ kg.ha ${ }^{-}$ ${ }^{1}$ NPK 20:10:10 setara 4,2 kg.petak ${ }^{-}$ ${ }^{1} ; \mathrm{p} 2=500 \mathrm{~kg} \cdot \mathrm{ha}^{-1}$ NPK 17:9:11 setara 4,2 kg.petak ${ }^{-1} ; \quad$ p3 $=500$ kg.ha ${ }^{1} 16: 16: 16$ setara 4,2 kg.petak ${ }^{-1}$ dan $\mathrm{p} 4$ $=500 \mathrm{~kg} \cdot \mathrm{ha}^{-1}$ setara 4,2 kg.petak ${ }^{1} 15: 20: 13$ setara 4,2 kg.petak ${ }^{-1}$.

\subsection{Prosedur Penelitian}

2.4.1. Persiapan lahan dan pembuatan petak penelitian. Lahan yang telah dibersihkan kemudian diolah sampai gembur. Selanjutnya ditabur kapur dolomit sebanyak 15 kg.petak ${ }^{-1}$ dan permukaan tanahnya diratakan. Petak penelitian dibuat sebanyak 25 berukuran $12 \mathrm{~m}$ x $7 \mathrm{~m}$, dengan jarak antar petak $1 \mathrm{~m}$.

2.4.2. Penanaman dan jarak tanam. Benih ditanam secara tugal sedalam 2-3 cm dengan jarak tanam $20 \mathrm{~cm} \times 70 \mathrm{~cm}$ setelah benih di tanam kemudian di tutup dengan tanah.

2.4.3. Perlakuan pemupukan. Pupuk diberikan secara tugal diantara barisan tanaman pada umur 15 dan 30 hari setelah tanam, masing-masing sebanyak 2,1 $\mathrm{kg} \cdot$ petak $^{-1}$ sesuai dengan perlakuan kandungan pupuk majemuk.

2.4.4. Pemeliharaan meliputi penyiraman yang disesuaikan dengan kondisi kelembaban tanah, penyulaman pada umur 7 hari setelah tanam, penyiangan gulma pada umur 15, 30, 45 dan 60 hari setelah tanam, pemangkasan batang 7 hari sebelum panen yang menyisakan setengah bagian tanaman.

2.4.5. Pemanenan dilakukan dengan kriteria klobot berwarna coklat muda dan kering, bijinya mengkilat,ada tanda hitam (black layer) pada pangkal bijinya (80100 hari).

\subsection{Pengumpulan Data}

Parameter tanaman yang diukur meliputi tinggi tanaman $(\mathrm{cm})$, diameter batang $(\mathrm{cm})$, jumlah daun (helai), panjang tongkol $(\mathrm{cm})$, diameter tongkol $(\mathrm{cm})$, jumlah baris biji per tongkol (baris), jumlah biji 
dalam baris (butir), berat biji per tongkol $(\mathrm{g})$, berat biji per 100 butir (g), potemsi hasil $\left(\mathrm{Mg}_{\mathrm{g}} \mathrm{ha}^{-1}\right)$.

\subsection{Analisis Data}

Data yang diperoleh dianalisis sidik ragam. Bila terdapat perbedaan nyata, maka untuk membandingkan dua rata-rata antar perlakuan digunakan uji Beda Nyata Terkecil (BNT) pada taraf 5\%.

\section{HASIL PENELITIAN DAN PEMBAHASAN}

3.1. Tinggi Tanaman $(\mathrm{cm})$ dan Jumlah Daun (helai) Umur 15, 30 dan 45 Hari Setelah Tanam (HST)

Hasil analisis ragam menunjukkan bahwa pemberian beberapa komposisi pupuk majemuk pada lahan pasca tambang batubara berbeda tidak nyata terhadap tinggi tanaman dan jumlah daun jagung (Zea mays L.) umur 15, 30 dan 45 HST (Tabel 1).

Tabel 1. Pemberian Beberapa Komposisi Pupuk Majemuk Pada Lahan Pasca Tambang BatubaraTerhadap Tinggi Tanaman (cm) dan Jumlah Daun Jagung (Zea mays L.) (helai) Umur 15, 30 dan 45 HST

\begin{tabular}{|c|c|c|c|c|c|c|}
\hline \multirow{2}{*}{ Perlakuan } & \multicolumn{3}{|c|}{ Tinggi Tanaman (Hari Setelah Tanam)(cm) } & \multicolumn{3}{|c|}{ Jumlah Daun (Hari Setelah Tanam)(helai) } \\
\hline & 15 & 30 & 45 & 15 & 30 & 45 \\
\hline p0 & 23,75 & 57,21 & 110,75 & 3,25 & 6,58 & 8,00 \\
\hline $\mathrm{p} 1$ & 21,06 & 71,88 & 176,62 & 3,45 & 7,47 & 10,17 \\
\hline $\mathrm{p} 2$ & 21,09 & 75,18 & 170,50 & 3,63 & 7,71 & 10,03 \\
\hline p3 & 17,27 & 75,41 & 168,60 & 3,00 & 7,30 & 10,24 \\
\hline $\mathrm{p} 4$ & 12,85 & 64,16 & 163,79 & 2,11 & 6,65 & 9,76 \\
\hline
\end{tabular}


3.2. Diameter Batang $(\mathrm{cm})$ Umur 15, 30 dan 45 HST, Panjang Tongkol $(\mathrm{cm})$ dan Diameter Tongkol Jagung (Zea mays L.) (cm) Waktu Panen

Hasil analisis ragam menunjukkan bahwa pemberian beberapa komposisi pupuk majemuk pada lahan pasca tambang batubara berbeda tidak nyata terhadap diameter batang $(\mathrm{cm}) 15,30$ dan 45 HST, panjang tongkol $(\mathrm{cm})$ dan diameter tongkol Jagung (Zea mays L.) (cm) Waktu Panen (Tabel 2).

Tabel 2. Pemberian Beberapa Komposisi Pupuk Majemuk Pada Lahan Pasca Tambang Batubara Terhadap Diameter Batang $(\mathrm{cm})$ 15, 30 dan 45 HST, Panjang Tongkol $(\mathrm{cm})$ dan Diameter Tongkol Jagung (Zea mays L.) (cm) Waktu Panen

\begin{tabular}{|c|c|c|c|c|c|}
\hline & \multicolumn{3}{|c|}{$\begin{array}{c}\text { Diameter Batang (Hari Setelah } \\
\text { Tanam })(\mathrm{cm})\end{array}$} & $\begin{array}{l}\text { Panjang Tongkol } \\
(\mathrm{cm})\end{array}$ & $\begin{array}{l}\text { Diameter Tongkol } \\
(\mathrm{cm})\end{array}$ \\
\hline & 15 & 30 & 45 & Panen & Panen \\
\hline $\mathrm{p} 0$ & 0,29 & 0,71 & 1,34 & 10,22 & 3,56 \\
\hline $\mathrm{p} 1$ & 0,33 & 1,03 & 1,96 & 15,08 & 4,17 \\
\hline $\mathrm{p} 2$ & 0,37 & 1,08 & 1,89 & 14,92 & 4,37 \\
\hline p3 & 0,23 & 1,11 & 1,91 & 14,96 & 4,28 \\
\hline $\mathrm{p} 4$ & 0,18 & 0,88 & 1,98 & 15,34 & 4,16 \\
\hline
\end{tabular}

Pemberian beberapa komposisi pupuk majemuk terhadap tinggi tanaman, jumlah daun dan diameter batang tanaman jagung (Zea mays L.) pada lahan pasca tambang batubara umur 15, 30 dan 45 HST menunjukkan berbeda tidak nyata (lihat Tabel 1 dan 2). Pertumbuhan tanaman yang rendah dijumpai pada perlakuan tanpa pupuk majemuk (p0), hal ini diduga karena tidak adanya pasokan hara dari luar maka kebutuhan hara tanaman hanya bersumber dari lahan pasca tambang batubara yang memiliki kesuburan tanah yang rendah. Menurut Kasno dan Rostaman (2013) kekurangan unsur hara tertentu dalam tanaman dapat berakibat kurang optimalnya tanaman. Iskandar (2013) menambahkan bila tanaman jagung kekurangan salah satu unsur hara makro maka dapat mengurangi efisiensi unsur hara lainnya sehingga menghambat pertumbuhan

Namun bila dibandingkan dengan tanpa pemupukan (kontrol), maka perlakuan yang diberi pupuk cenderung menunjukan pertumbuhan tinggi 
tanaman, jumlah daun dan diameter batang yang lebih baik. Hal ini diduga karena pada perlakuan pupuk majemuk $\mathrm{NPK}$, unsur hara $\mathrm{N}, \mathrm{P}$ dan $\mathrm{K}$ tersedia dalam jumlah yang optimal dan seimbang sehingga mampu memberikan keseimbangan hara makro bagi tanaman. Ashgar, dkk. (2010) menyatakan untuk dapat tumbuh dengan baik tanaman membutuhkan hara $\mathrm{N}, \mathrm{P}$ dan $\mathrm{K}$ yang sangat berperan dalam pertumbuhan tanaman secara umum pada fase vegetatif. Mamoto (2015) menambahkan pupuk NPK sangat dibutuhkan untuk merangsang pembesaran diameter batang, pembentukan akar serta pembentukan tinggi tanaman dan pasokan $\mathrm{K}$ yang memadai menurut Ademiluyi dan Fabiyi (2015) akan membantu tanaman membentuk diameter batang yang lebih besar.

Pemberian berbagai komposisi pupuk majemuk menghasilkan tanaman yang lebih tinggi di bandingkan dengan perlakuan tanpa pupuk. Hal ini disebabkan dengan pemberian pupuk majemuk NPK akan meningkatkan ketersediaan unsur hara $\mathrm{N}$ yang sangat dibutuhkan untuk pertumbuhan vegetatif tanaman. Seperti dikemukakan oleh Nurdin, dkk. (2010) bahwa unsur hara N diperlukan tanaman untuk pembentukan klorofil dan merangsang pertumbuhan vegetatif tanaman seperti batang, cabang dan daun. Ademiluyi (2015) menambahkan $\mathrm{N}$ merupakan komponen yang dikaitkan dengan aktivitas fotosintesis yang tinggi, pertumbuhan vegetatif yang kuat dan warna hijau tua pada daun.
Menurut Fadwiwati dan Tahir (2013) nitrogen merupakan hara esensial yang berfungsi sebagai bahan penyusun asam-asam amino, protein, dan bahan penyusun komponen inti sel, sehingga pemupukan NPK yang cukup dan berimbang dapat meningkatkan pertumbuhan jagung lebih baik. Kasno dan Rostaman (2013) menambahkan ketersediaan hara yang cukup dan seimbang akan mempengaruhi proses metabolisme pada jaringan tanaman yaitu pembentukan dan perombakan unsur hara dan senyawa organik dalam tanaman.

Tidak semua pupuk majemuk yang diberikan ke dalam tanah dapat diserap oleh tanaman jagung. Menurut Ashgar, dkk. (2010) N yang dapat diserap hanya sekitar 55-60\% P sekitar 20\%, K antara 50-70\%. Sementara menurut Ademiluyi dan Fabiyi (2015) sekitar 33\% Subekti dkk. (2017) menambahkan pada masa vegetatif akhir tanaman menyerap unsur hara $\mathrm{P}$ sekitar 50\% lalu diikuti oleh $\mathrm{N}$ dan $\mathrm{K}$ masing-masing sebesar $60 \%$ sampai $70 \%$ dan $80 \%$ sampai $90 \%$.

\subsection{Jumlah Baris Biji (baris), Jumlah Biji} Dalam Baris (butir), Berat Biji per Tongkol (g), Berat Biji per 100 Butir (g) dan Hasil Pipilan kering Jagung (Zea mays L.) (Mg.ha-1) Waktu Panen

Hasil analisis ragam menunjukkan bahwa pemberian beberapa komposisi pupuk majemuk pada lahan pasca tambang batubara berbeda tidak nyata terhadap jumlah baris biji (baris), jumlah biji dalam baris (butir), berat biji per tongkol $(\mathrm{g})$, berat biji per 100 butir $(\mathrm{g})$ dan hasil pipilan kering Jagung (Zea mays L.) (Mg.ha $\left.{ }^{-1}\right)$ Waktu Panen (Tabel $3)$. 
Tabel 3. Pemberian Beberapa Komposisi Pupuk Majemuk Pada Lahan Pasca Tambang Batubara Terhadap Jumlah Baris Biji (baris), Jumlah Biji Dalam Baris (butir), Berat Biji Per Tongkol (g), Berat Biji Per 100 butir (g) dan Hasil Pipilan Kering Jagung (Zea mays L.) (Mg.ha'-1) Waktu Panen Waktu Panen

\begin{tabular}{|c|c|c|c|c|c|}
\hline arlakuan & $\begin{array}{l}\text { Jumlah Baris } \\
\text { Biji (baris) }\end{array}$ & $\begin{array}{l}\text { Jumlah Biji } \\
\text { Dalam Baris } \\
\text { (butir) }\end{array}$ & $\begin{array}{l}\text { Berat Biji Per } \\
\text { Tongkol (g) }\end{array}$ & $\begin{array}{l}\text { Berat Biji Per } \\
100 \text { Butir (g) }\end{array}$ & 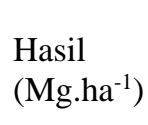 \\
\hline
\end{tabular}

Panen Panen Panen Panen

\begin{tabular}{|c|c|c|c|c|c|}
\hline $\mathrm{p} 0$ & 12,03 & 20,22 & 100,50 & 25,22 & 5,04 \\
\hline $\mathrm{p} 1$ & 12,65 & 27,04 & 112,74 & 30,56 & 6,17 \\
\hline $\mathrm{p} 2$ & 13,13 & 30,07 & 115,98 & 30,89 & 6,20 \\
\hline p3 & 13,14 & 29,86 & 115,99 & 31,27 & 6,37 \\
\hline $\mathrm{p} 4$ & 12,94 & 27,31 & 114,69 & 31,22 & 6,28 \\
\hline
\end{tabular}

Pemberian beberapa komposisi pupuk majemuk terhadap panjang dan diameter tongkol, jumlah baris biji, jumlah biji dalam baris, berat biji per tongkol, berat biji per 100 butir, dan hasil tanaman jagung (Zea mays L.) pada lahan pasca tambang batubara saat panen menunjukkan berbeda tidak nyata (lihat Tabel 2 dan 3). Perkembangan tanaman yang rendah dijumpai pada perlakuan tanpa pupuk majemuk (p0), hal ini diduga karena kebutuhan hara tanaman hanya bersumber dari lahan pasca tambang batubara yang memiliki kesuburan tanah yang rendah sehingga kurang mampu untuk menunjang perkembangan tanaman yang maksimal. Iskandar (2013) menyatakan bahwa tanaman tidak akan memberikan hasil yang maksimal apabila unsur hara yang diperlukan tidak tersedia. Ketersediaan unsur hara merupakan salah satu faktor yang dapat mempengaruhi tingkat produksi suatu tanaman.

Menurut Mamonto (2015) melalui pemupukan diharapkan dapat memperbaiki kesuburan tanah, antara lain menggantikan unsur hara yang hilang karena pencucian atau erosi dan yang terangkut oleh panen.

Perlakuan pupuk majemuk NPK memberikan panjang dan diameter tongkol, jumlah baris biji, jumlah biji dalam baris, berat biji per tongkol, berat biji per 100 butir lebih baik dibandingkan kontrol. Pemberian pupuk majemuk dapat meningkatkan ketersediaan unsur hara $\mathrm{N}$, $\mathrm{P}$, dan $\mathrm{K}$ yang berpengaruh terhadap 
meningkatnya serapan unsur hara oleh tanaman sehingga dapat memberikan hasil tongkol yang lebih baik. Seperti dinyatakan oleh Raihan (2010) bahwa pemberian pupuk NPK dapat memperbesar ukuran buah, biji dan umbi hasil panen. Menurut Noviana (2011) karakter panjang tongkol menunjukkan kepadatan biji dan erat kaitannya dengan jumlah biji per tongkol. Jika tanaman kekurangan $\mathrm{N}$ dan $\mathrm{P}$ akan menyebabkan perkembangan tongkol tidak sempurna,

Hara NPK akan ditranslokasikan pada pembentukan tongkol dan pengisian biji sehingga diameter tongkol akan meningkat. Unsur $\mathrm{P}$ sangat dibutuhkan tanaman dalam pembentukan tongkol (Mapegau, 2010). Hasil penelitian Syarifuddin dan Suwarti (2012), dosis N mengakibatkan perbedaan panjang tongkol. Novriani (2010) menambahkan pemupukan dapat meningkatkan panjang tongkol dan diameter tongkol jagung. Menurut Sirajuddin (2010) ukuran lingkar tongkol berpengaruh terhadap produksi karena semakin besar lingkar tongkol, maka nilai bobot tanaman akan semakin tinggi.

Hasil penelitian Maqsood et al (2010), dan Sharer et al (2013) bahwa, jumlah dan bobot 100 biji meningkat pada dosis pupuk tertentu. Menurut Noviana (2011), tongkol yang lebih panjang berpeluang dalam memberikan hasil yang lebih tinggi, karakter panjang tongkol menunjukkan kepadatan biji dan erat kaitannya dengan jumlah biji per tongkol. Marvelia, et al (2016) menambahkan peran unsur hara $\mathrm{P}$ dalam pembentukan bunga mempengaruhi pembentukan dan ukuran tongkol, karena tongkol merupakan perkembangan dari bunga betina

Bobot pipilan kering berkaitan dengan besarnya translokasi fotosintat ke dalam biji. Menurut Rahni (2012) peningkatan bobot kering biji berkaitan dengan besarnya translokasi fotosintat ke dalam biji dan semakin baiknya sistem perakaran tanaman untuk dapat mengabsorbsi unsur hara dari dalam tanah. Translokasi fotosintat yang cukup besar ke organ reproduktif menyebabkan pembentukan tongkol dan pengisian biji berlangsung dengan baik dan biji yang terbentuk berukuran lebih besar. Kasno dan Rostaman (2013) menambahkan bila tanaman kekurangan nutrisi sebelum pembentukan bunga jantan maka akan mengurangi jumlah bakal biji yang terbentuk.

Pemberian beberapa komposisi pupuk majemuk memberikan hasil tanaman jagung (Zea mays L.) lebih baik bila dibandingkan dengan perlakuan kontrol. Penelitian Ashgar et al, (2010) hasil tanaman jagung meningkat dengan penggunaan pupuk NPK. Menurut Taufik, dkk. (2014) ketersediaan unsur hara berkaitan dengan proses pengisian biji. Unsur hara yang diserap akan diakumulasikan ke daun menjadi protein yang membentuk biji. Akumulasi bahan hasil metabolisme pada pembentukan biji akan meningkat, sehingga biji yang terbentuk memiliki ukuran dan berat yang maksimal, hal ini terjadi apabila terpenuhinya kebutuhan unsur hara yang menyebabkan metabolisme berjalan secara optimal. Pemberian dosis pupuk yang tepat perlu dilakukan untuk menyeimbangkan hara sehingga tanaman dapat tumbuh dan berkembang dengan baik (Taufik dan Nappu, 2015). Hasil jagung dapat ditingkatkan dengan pemupukan yang tepat baik dosis dan waktu maupun jenis pupuk yang diberikan. Hara N, P dan K merupakan hara makro yang sangat penting bagi pertumbuhan dan perkembangan tanaman (Purba, 2017)

Sementara rendahnya hasil jagung pada perlakuan kontrol, diduga tanaman kekurangan unsur $\mathrm{N}, \mathrm{P}$ dan $\mathrm{K}$. Hal ini sejalan dengan pendapat Syafruddin (2011) bahwa kondisi lahan yang kurang 
subur menyebabkan produktifitas yang rendah. Menurut Ruchjaniningsih et al., (2013) kekurangan fosfor berpengaruh terhadap metabolisme dan pertumbuhan khususnya pembentukan tongkol dan biji sedangkan kekurangan kalium dapat menurunkan hasil jagung $10 \%$. Kekurangan $\mathrm{N}$ akan menyebabkan tanaman jagung mempunyai pertumbuhan vegetatif yang tinggi tetapi hasil panen rendah. Weith dkk., (2011) menambahkan kekurangan unsur hara $\mathrm{P}$ yang tersedia menyebabkan produksi merosot.

\section{KESIMPULAN}

Berdasarkan hasil penelitian pertumbuhan dan hasil tanaman jagung (Zea mays L.) terhadap pemberian beberapa komposisi pupuk majemuk pada lahan pasca tambang batu bara dapat disimpulkan sebagai berikut:

1. Perlakuan beberapa komposisi pupuk majemuk NPK menunjukkan perbedaan tidak nyata terhadap semua parameter yang diamati yaitu tinggi tanaman, diameter batang, jumlah daun, panjang tongkol, diameter tongkol, jumlah baris biji, jumlah biji dalam baris, berat biji per tongkol, berat jagung per 100 butir, dan hasil.

2. Perlakuan komposisi pupuk majemuk 16:16:16 cenderung memberikan hasil lebih baik yaitu 6,37 Mg.ha ${ }^{-1}$ dibandingkan dengan perlakuan lainnya.

\section{DAFTAR PUSTAKA}

Ademiluyi BO, Fabiyi EP. (2015). Response of Hybrid Maize (Zea mays L.) to Organic and Inorganic Fertilizers in Soils of South-West and North-Central Nigeria. Journal Plant Soil Sci 7(2): 121-127.
Asghar A, Ali A, Syed W.H, Asif M.T, Khaliq, Abid A.A. (2010). Growth and Yield of Maize Cultivars Affected by NPK Application in Different Proportion. Pakistan Journal Sci 62(4): 211-216

Bappeda Provinsi Kalimantan Timur, (2016). Rencana Tata Ruang dan Wilayah Propinsi Kalimantan Timur.

Dariah, A., A. Abdurachman dan D. Subardja. (2010). Reklamasi Lahan Pasca Penambangan untuk Perluasan Areal Pertanian. Jurnal Sumberdaya Lahan 4(1):1-12. ISSN 1907-0799.

Cooke, G.W. (2015). Fertilizing for Maximum Yield. Granada Publishing Limited. London. P. 7587.

Fadwiwati, A,Y dan A.G.Tahir (2013). Analisis Faktor-faktor yang Mempengaruhi Produksi dan Pendapatan Usahatani Jagung di Provinsi Gorontalo. Jurnal Pengkajian dan Pengembangan Teknologi Pengkajian 16 (2) : 92101

Hadijah, A.D. (2010). Peningkayan Produksi Jagung Melalui Penerapan Inovasi Pengelolaan Tanaman terpadu. Jurnal Iptek Tanaman Pangan 5 (1): 64-73

Iskandar, D. (2013). Pengaruh Dosis Pupuk N, P, K Terhadap Pertumbuhan dan Produksi Jagung Manis di Lahan Kering. Prosiding Seminar Teknologi untuk Negeri 2003, 2: $1-5$

Kasno A. dan Tia Rostaman. (2013). Serapan Hara dan Peningkatan Produkstivitas Jagung dengan Aplikasi Pupuk NPK Majemuk. 
Jurnal Penelitian Pertanian Tanaman Pangan. 32 (3): 176-186.

Kumar, A., and A. Ch. Pandey. (2013). Evaluating Impact of Coal Mining Activity Landuse/ Landcover Using Temporal Satellite Images in South Karanpura Coalfields and Environs, Jharkhand State, India. IJARSGAn Open Access International Journal. ISSN 2320 - 0243.

Kumar, B. M. (2013). Mining Waste Contaminated Lands: an Up Hill Battle for Improving Crop Productivity. College of Forestry, Kerala Agricultural University, Thrissur, Kerala. Journal of Degraded and Mining Lands Management 1 (1): 4350. ISSN: 2339-076X.

Lingga, P dan Marsono. (2010). Petunjuk penggunaan pupuk. PT. Penebar Swadaya, Jakarta. $150 \mathrm{hlm}$

Mamonto, R. (2015). Pengaruh Penggunaan Dosis Pupuk Majemuk NPK Phonska terhadap Pertumbuhan dan Produksi Jagung Manis (Zea mays Saccharata). Skripsi. Fakultas Pertanian Universitas Icshan, Gorontalo.

Mapegau. (2010). Pengaruh Pemupukan $\mathrm{N}$ dan $\mathrm{P}$ terhadap Hasil Jagung Kultivar Arjuna pada Tanah Ultisol Batanghari Jambi. Jurnal Agronomi. 4 (1): 17-18.

Maqsood MA, Abid MA, Iqbal, Hussain MI. (2001). Effect of Variable Rate of $\mathrm{N}$ and $\mathrm{P}$ on Growth and Yield of Maize ((Zea mays L.). Journal Biology Science 1: 19-20.

Marvelia, A., S. Darmanti, dan S. Parman. (2016). Produksi Tanaman Jagung Manis (Zea mays L. Saccharata) yang Diperlakukan dengan Kompos Kascing dengan
Dosis yang Berbeda. Buletin Anatomi dan Fisiologi 14(2): 7-18.

Mulyani SM. 2010. Pupuk dan Cara Pemupukan. Jakarta: PT Rineka Cipta.

Noviana I, Ishaq I. (2011). Karakter Hasil Galur dan Varietas Jagung pada MK II di Jawa Barat. Prosiding Seminar Nasional Pengkajian dan Diseminasi Inovasi Pertanian Mendukung Program Strategis Kementrian Pertanian. Cisarua 911.

Novriani. (2010). Alternatif Pengelolaan Unsur Hara P (Fosfor) Pada Budidaya Jagung. Jurnal Agronobis 2(2) : 42-49

Nurdin, Maspeke P., Illahude Z., dan F. Zakaria. 2010. Pertumbuhan dan Hasil Jagung yang Dipupuk N, P, dan $\mathrm{K}$ pada Tanah Vertisol Isimu Utara Kabupaten Gorontalo. Jurnal Tanah Tropika. 14(1): 49-56.

Purba, R. (2017). Pengkajian Pemupukan pada Usahatani Jagung di Lahan Kering dan Lahan Sawah di Kabupaten Pandeglang Banten. Jurnal Agribisnis dan Sosial Ekonomi Pertanian 2 (1): 205-290

Rahni NM. (2012). Efek Fitohormon PGPR terhadap Pertumbuhan Tanaman Jagung (Zea mays L.). Jurnal Agribisnis Pengembangan Wilayah 3(2): 27-35.

Raihan, H.S. (2010). Pemupukan NPK dan Ameliorasi Lahan Pasang Surut Sulfat Masam Berdasarkan Nilai Uji Tanah Untuk Tanaman Jagung. Jurnal Ilmu Pertanian 9 (1): 20-28 
Ramayana, A.S. (2015). Studi Kondisi Biogeofisik Lahan untuk Desain Pemanfaatan Lahan Pasca Tambang Batubara. Disertasi Fakultas Kehutanan Universitas Mulawarman, Samarinda.

Ruchjaniningsih, M. Thamrin dan M. Taufik. (2013). Respon varietas jagung terhadap nitogen di lahan sawah dan lahan kering. Jurnal Pengkajian dan Pengembangan Teknologi Pengkajian 16 (3):183189.

Sharer MS, Ayub M, Nadeem MA, Ahmad N. (2013). Effect of Different rates of $\mathrm{N}$ and $\mathrm{P}$ on Growth and Grain Yield of Maize. Journal Asian Plant Science 2(3): 347-349.

Sirajuddin, M. (2010). Komponen Hasil dan Kadar Gula Jagung Manis (Zea mays L. Sacharata) Terhadap Pemberian Nitrogen dan Zat Tumbuh Hidrasil. Fakultas Pertanian UNTAD, Palu.

Subekti NA, Syafiruddin, Efendi R, Sunarti S. (2017). Morfologi Tanaman dan Fase Pertumbuhan Jagung. Balai Penelitian Tanaman Serealia Sulawesi Selatan. URL: http://balitsereallitbang.deptan.co.id
Sulaiman, A.A., I.K Kariyasa, Hoerudin, K. Subagyono, F.A. Bahar. (2018). Cara Cepat Swasembada Jagung. IAARD Press. Badan Penelitian dan Pengembangan Pertanian, Jakarta. $140 \mathrm{hlm}$

Syafruddin. (2011). Modifikasi Sistim Pertanaman Jagung dan Pengolahan Brangkasan untuk Meningkatkan Pendapatan Petani di Lahan Kering. Jurnal Penelitian dan Pengembangan Pertanian. 30 (1): 263-272

Syarifuddin, M, Suwarti. (2012). Pengembangan Jagung Toleran Naungan dan $\mathrm{N}$ rendah pada Lahan Diantara Tanaman Perkebunan. Jurnal Ilmu Pertanian 9 (1): 20-28

Taufiq, M., Kuntyastuti H, A.G. Manshuri. (2014). Pemupukan dan Ameliorasi Lahan Kering untuk Peningkatan Produktivitas Kedelai. Prosiding Lokakarya Pengembangan Kedelai Melalui Pendekatan Pengelolaan Tanaman Terpadu di Lahan Kering. Balai Penelitian Aneka Kacang dan Umbi. 
Taufik, M., Maintang, M.B. Nappu. (2015). Kelayakan Usaha Tani Jagung di Sulawesi Selatan. Jurnal Pengkajian dan Pengembangan Teknologi Pertanian 18 (1) : 67-80.
Weith, M,. L. Asplund, and G. Bergkvist. (2011). Assesment of Nutrient use in Annual and Perennial Crops : A Functional Concept for Analizing Nitrogen Use Eficiency. Journal Plant Soil 339 : 513-520. 